\title{
Remote Sensing in Pre-earthquakes Exploration, Case Study of Zagreb Region, Croatia
}

\author{
Marinko Oluic \\ GEOSAT Ltd., Croatia
}

Copyright (C) 2015 by authors, all rights reserved. Authors agree that this article remains permanently open access under the terms of the Creative Commons Attribution License 4.0 International License

\begin{abstract}
Broader region of the Zagreb city is seismotectonically very active. In that region are located several epcentral areas with strong earthquakes. The most active is Medvednica Mountain near Zagreb city. The main cause of these earthquakes is major intersecting faults with longitudinal (NW-SE) and transverse (NE-SW) strike. The LANDSAT digital processed images were used for seismotectonical analysis and registration of different tectonical elements, particularly major faults and ring structures in this region. The earthquake epicentres occurred more often along these faults and at their intersections, which have various orientations. This fact could be valuable for local governments to help in city planning and capital investments in infrastructure and construction.
\end{abstract}

Keywords Landsat, Tectonic, Earthquakes, Zagreb Region

\section{Introduction}

Croatia belongs to the Mediterranean-Transasiatic seismic zone, which is one of the seismically most active zones of Europe, as well as in the world, with high seismic risks. This zone is located in wide area between two large tectonic plates, African and Eurasian. Within this zone, several smaller tectonic plates can be differentiated, such as Adriatic microplate which belong Croatia are. Statistical data show that in Croatia annually on an average occur several hundreds of earthquakes with magnitudes $M \geq 3.0$. Moreover, the Croatia and neighboring region is struck by at least one major earthquake each $10-15$ years, and by a catastrophic earthquake once in 60 - 70 years.

In historical times, in Zagreb region occurred several devastating earthquakes. Among others the earthquake occurred in Zagreb area in 1880 was the strongest one. The causes of earthquakes in this region are related to tectonic movements. Seismotectonically most active are bordering (fault) zones between large geotectonical units, and there occurred earthquakes with the highest magnitudes.
Epicenters are located in particular bordering zones, amongst which are distinctive zones, for example the zone that strikes from Banja Luka (Bosnia), Zagreb (Croatia), Ljubljana (Slovenia) and further towards Tolmezzo in Friuli (Italy). Broader Zagreb region is seismotectonically very active. In that region are located several epicentral areas, with strong earthquakes. The most active is Medvednica Mountain near Zagreb city. The main cause of these earthquakes is major intersecting faults with longitudinal and transverse strike. The Landsat satellite digital processed images were used for seismotectonical analysis and registration of major faults and ring structures in this region. The stronger earthquake epicentres, instrumentally registered, occurred more often along these faults and at their intersections, which have various orientations. That has been showed on so created tectonic map.

\section{Tectonic Based on Landsat Imagery}

Landsat images have been used for analysis and interpretation of tectonic relations (Figure 1). On the digitally processed Landsat imagery numerous of tectonic elements, particularly faults of diverse intensity and orientation and ring structures have been registered (Figure 2). They are mainly consequences of the recent tectonic activity, or re-activited paleotectonic faults, which were accomplished by differentiated vertical and sub-vertical mass movements. The above mentioned area belongs to the Alpine orogen which suffered strong tectonic disturbances in geological history, which act even today causing strong seismic activity and earthquakes. They have given shape to the current morphostructure of the terrain. Namely, the principal morphostructures have two main directions of spreading: longitudinal (NW-SE) and transverse (NE-SW). The same orientation have the most prominent faults trending longitudinal which strikes for the most of its length along the Sava River valley, therefore named the Sava fault or fault zone. The mentioned fault can be followed on Landsat images having intervals from Banja Luka-Zagreb Ljubljana and further towards Tolmezzo in Friuli (Italy), in 
length of more than $350 \mathrm{~km}$. It was intrrupt with several transwerse or diagonal faults. Perpendicularly or diagonally faults strike and run along the Medvednica Mountain in northeast direction. These faults are intersecting or colliding in the Zagreb area (Figure 2). They caused very active tectonic relations as well as very intensive seismotectonic activities with relatively often earthquakes.

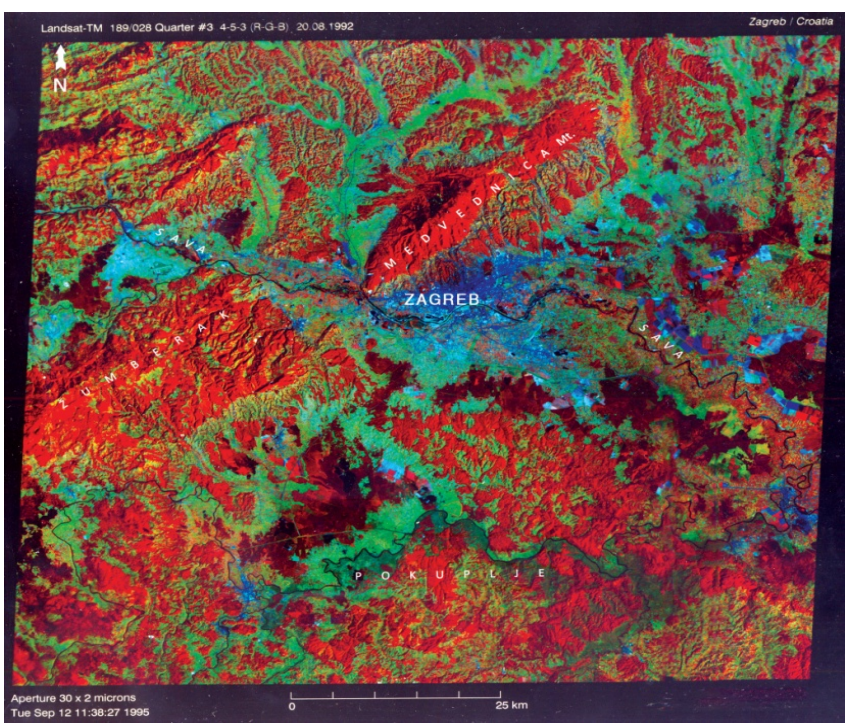

Figure 1. Landsat colour composite of the wider Zagreb area

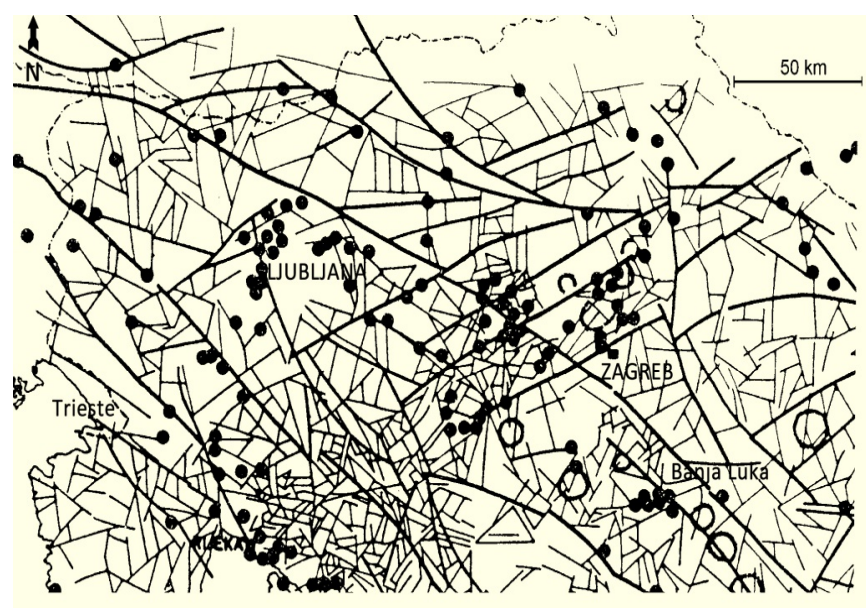

Legend: - Major faults _ Fractures $\bigcirc$ Ring structures

- Epicentres of stronger earthquakes

Figure 2. Tectonical map based on LANDSAT imagery of the northwestern part of Croatia (broader Zagreb area) and part of Slovenia, with epicentres of stronger earthquakes, with magnitude $M>4.5$, Oluić \& Cvijanović [4]

\section{Seismicity}

Zagreb region is one of the seismically most active regions in continental part of Croatia. This region comprises several epicentral areas with increased seismic activity. More important are Medvednica Mountain, Pokuplje and Žumberak. The importance of this epicentral area is shown in the map of spatial distribution of stronger earthquake epicentres (Figure 2). Seismicity there is caused by tectonical disturbances, particularly intersection of major faults of various orientations (longitudinal and transverse/diagonally). The region is seismotectonically very active. The largest concentration of earthquakes is recorded in wider area of Zagreb city. Historically, the area was struck by several strong earthquakes, the strongest one in Medvednica Mountain in 1880 and is known as the „Zagreb earthquake " with estimated $M=6.3$ Richter magnitude, $I_{0}=$ $\mathrm{IX}^{0}$ MCS intensity, and $10 \mathrm{~km}$ deep focus. This earthquake was disastrous leveling about 1,700 houses. The last stronger earthquake happened in Medvednica Mountain 1990, its magnitude was $M=4.9$ and epicentral intensity $I_{0}=\mathrm{VII}^{0}$ MCS. Probabilistic seismic hazard analysis (PSHA) indicates that strong earthquakes with magnitudes up to 6.5 can be expected here.

In Pokuplje area (south from Zagreb - along the Kupa River) strong earthquake occurred in 1909 with $M=6.0$ Richter magnitude and intensity $I=$ VIII - IX $^{0}$ MCS. Its hypocentral depth was $10 \mathrm{~km}$, too. This earthquake is known, because based on its data A. Mohorovičić has been establish discontinuity between Earth's Crust and Mantle - MOHO Discontinuity, Mohorovicic [3].

In Žumberak Mountain (southwest from Zagreb city) the strongest recorded earthquake occurred in 1917, its epicentral intensity was $I_{0}=\mathrm{VIII}^{0} \mathrm{MCS}$, magnitude $M=5.7$, and focal depth of $6 \mathrm{~km}$.

Generally, it is possible to recognise two main directions of spreading of epicentre locations, which coincides with major faults, i.e. direction northeast-southwest and northwest-southeast (Figure 3 and Figure 4). It becomes evident that the earthquake epicentres are grouped along major faults and at the places of faults intersections.

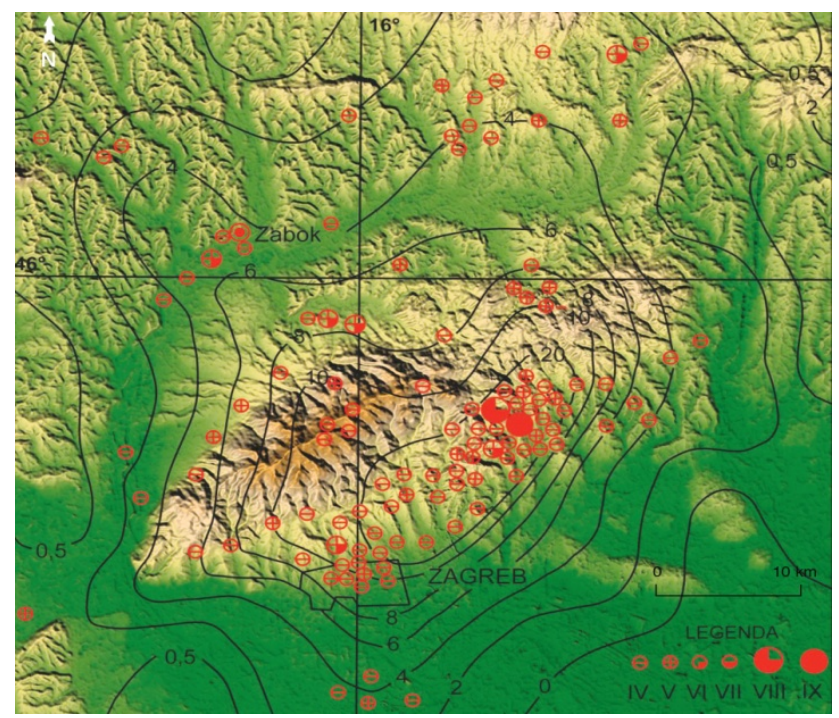

Figure 3. Landsat colour composite with isolines of stronger earthquake epicentres and frequency spreading diagonal in northeast-southwest direction (Cvijanović at al. [1]; Oluić [5]

In the Figure 3 have been showed contours of equivalent 
frequency of the stronger earthquake epicentres $(M \geq 3.7$ Richter): 0.5, 2, 4, 6, 8, 10, 20 earthquakes, for period 1879 1964, Cvijanović at al. [1]

It is visible that majority of epicenter locations of stronger earthquakes are concentrated northeast from Zagreb city in southeast of Medvednica Mountain slope (20 earthquakes). They spread in northeast-southwestern direction; that are showing the elongation of contours, too. The earthquake epicentres are located predominantly along the stronger faults, or at the intercections of the faults of different directions (Figure 2).

In addition to the perpendicular/diagonal zone where stronger and most frequent earthquakes occurred, it is possible to identify longitudinal zone (Dinaric orientation) spreading in northwest-southeast direction (Figure 4).

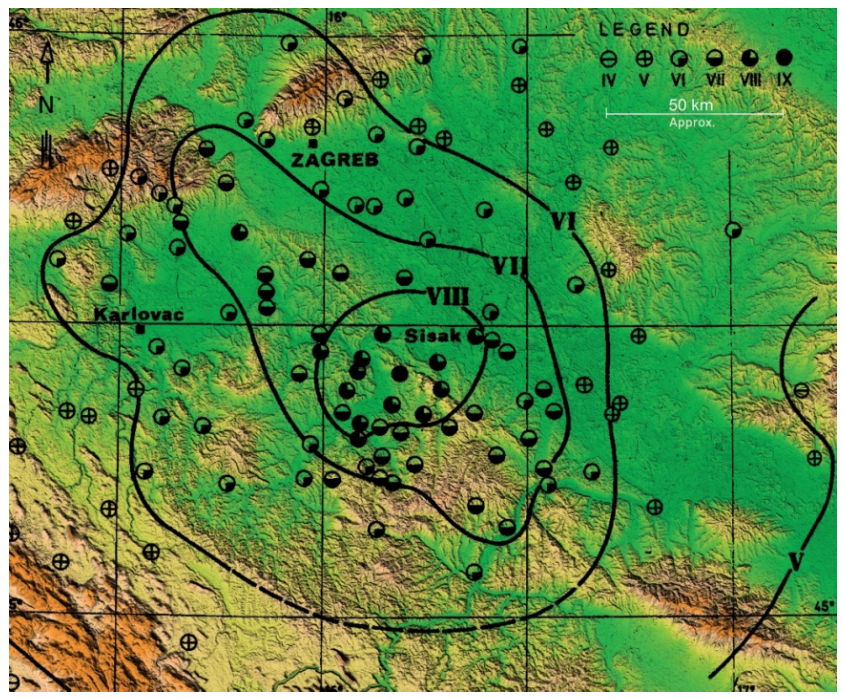

Figure 4. Landsat colour composite with isoseismal intensity map of earthquake and epicentres of stronger earthquakes spreading longitudinal in NW-SE direction (Cvijanović [2]; Oluić [5]

Figure 4 shows the isoseismal intensity map for earthquakes that occurred in Pokuplje area (Sisak) 1909. It is obvious that isoseismal lines are elongated in the northwest-southeastern direction. That means that the majority of earthquake epicentres were located and grouped along the main dislocations and in places of intersection of faults striking into different directions.

\section{Conclusions}

By the analysis of Landsat images, faults from most often the neotectonic period, which had given shape to the current morphostructure of the terrain, have been registered.
Tectonic data, particularly major faults from neotectonic period, registered on satellite images are very useful for pre-earthquakes instrumental seismic investigations. The epicentres of strong earthquakes, marked on the tectonic map, indicate a direct linkage between tectonic movements and earthquakes occurrence. Tectonic movements have predisposed unstable zones, within which more intense earthquakes occur mainly along strong ruptures, as well as they do at the intersections of diversely oriented ruptures. That fact shows a valuable piece of information for local governments, policy makers and practitioners to get an insight that will help them in city planning in unstable areas, capital investments in infrastructure and construction, seismic risk assessment and seismic risk reduction, with the special emphasis on disaster resilience in built environment.

\section{Acknowledgments}

This paper is an outcome of the research conducted in Geosat d.o.o., and preliminary reported in abstract form at the 4th International Conference on Building Resilience.

Incorporating the 3rd Annual Conference of the ANDROID Disaster Resilience Network held in Salford, United Kingdom in 2014. For fruitful discussions on seismicity over many years of cooperation, the author is indebted to Dr. Dragutin Cvijanovic.

\section{REFERENCES}

[1] D. Cvijanović et al. Seismic Characteristic of wider Area of Zagreb. Geophysical Institute- Faculty of sciences (PMF), Zagreb (in Croatian), 1967.

[2] D. Cvijanović. The Seismicity of Republic of Croatia. Doctoral dissertation, University of Zagreb (in Croatian), 1981.

[3] A. Mohorovičić. Earthquake of 8 October 1909 (Potres od 8. X 1909; Das Beben vom 8. X. 1909.). Yearly report of the Zagreb meteorological observatory for the year 1909 (Godišnje izvješće zagrebačkog meteorološkog opservatorija za godinu 1909), Zagreb, 63, 1910; English translation : Geofizika, Zagreb, 9, 3-55, 1992.

[4] M. Oluić, D. Cvijanović. Tectonic Elements Registered on the Landsat TM Imagery and Seismic Activity in the Western Part of Yugoslavia. $8^{\text {th }}$ Thematic Conference on Geologic Remote Sensing, Vol. II,1207-1214. Denver, Colorado, 1991.

[5] M. Oluić. Earthquake-Causes and Consequences with regards to Croatia and Neighboring Regions (in Croatian-Extended Summary in English), Prosvjeta, Zagreb, 346, 2015. 